\title{
Perancangan Sistem Pendukung Keputusan untuk Penentuan Subkontraktor dengan Metode Analytic Hierarchy Process (AHP) (Studi Kasus PT Aulia Pancang Gemilang)
}

\author{
Timothy John Pattiasina \\ Program Studi Manajemen Informatika \\ Institut Informatika Indonesia \\ temmy@ikado.ac.id
}

\author{
Sri Sukanti \\ Program Studi Sistem Informasi \\ Institut Informatika Indonesia
}

\begin{abstract}
Abstrak - Sistem Pendukung Keputusan (SPK) dapat digambarkan sebagai sistem yang berkemampuan mendukung analisis data, dan permodelan keputusan, berorientasi keputusan, orientasi perencanaan masa depan, dan digunakan pada saat - saat yang tidak biasa.

Sistem pengambilan keputusan juga membutuhkan teknologi informasi dalam aplikasinya, hal ini karena semakin lama perusahaan dituntut untuk bergerak cepat dalam mengambil sebuah keputusan dan tindakan. Metode Pengolahan Data dengan menggunakan Analytic Hierarchy Process (AHP) sangat membantu perusahaan karena dengan adanya kriteria dan subkriteria, AHP dapat memberikan hasil yang paling optimal / paling baik dengan menggunakan perankingan. Dengan contoh kasus seperti PT Aulia Pancang Gemilang, pengambilan keputusan untuk penentuan subkontraktor sangat diperlukan sehingga perusahaan dapat menemukan subkontraktor terbaik. Yang akan menentukan pada maksimalnya laba perusahaan.
\end{abstract}

Kata Kunci : Sistem Pendukung Keputusan, Analytical Hierarchy Proccess

\section{PENDAHULUAN}

Secara umum, teknologi informasi mencakup tiga hal, yaitu management information system, processing information system, decision information system. Teknologi informasi organisasi berfungsi memperlancar dalam perolehan dan penyimpanan data, dengan menggunakan berbagai fungsi software, selanjutnya dapat diinterpretasi dan ditransformasi menjadi informasi yang bermakna, dan memungkinkan transmisi informasi ini kepada para pengguna sehingga membantu mereka untuk mencapai tujuan dan sasaran organisasi. Sistem pengambilan keputusan juga membutuhkan teknologi informasi, hal ini dikarenakan adanya era globalisasi yang menuntut sebuah perusahaan untuk bergerak cepat dalam mengambil sebuah keputusan dan tindakan.

Selama ini pencarian subkontraktor masih di lakukan secara manual, perusahaan akan mencari perusahaan- perusahaan di daerah terdekat dengan proyek, kemudian mengundang penawaran (proposal), melakukan konfirmasi dan kemudian harus menunggu sampai dengan tercapainya kesepakatan. Hal ini memakan waktu yang panjang dan biaya yang lebih tinggi. Terkadang perusahaan juga tidak mendapatkan subkontraktor yang benar-benar pada spesifikasi barang dan harga terbaik. Dengan kondisi ini tentu menghambat proses pengambilan keputusan.

Dengan adanya kondisi di atas maka di perlukan sistem berbasis Teknologi Informasi yang dapat membantu perusahaan. Sistem ini diharapkan dapat mengeluarkan hasil yang lebih akurat dan dapat menghemat waktu yang biasanya dihabiskan dalam tahap pencarian subkontraktor.

\section{METODOLOGI PENELITIAN}

Dalam penelitian ini dijabarkan mengenai tinjauan pustaka yang menjadi dasar dilakukannya penelitian ini. Dimana seluruh tinjauan pustaka mencakup semua hal terkait dengan penelitian yang dilakukan.

\section{A. Sistem Pendukung Keputusan}

Untuk memberikan pengertian yang lebih mendalam, akan diuraikan melalui definisi mengenai Sistem Pendukung Keputusan (SPK). Decision Support Sistem (DSS) yang dikembangkan oleh beberapa ahli. Menurut Turban \& Aronson (1998) Sistem Pendukung Keputusan dapat dikategorikan sebagai sistem yang digunakan untuk mendukung dan membantu pihak manajemen melakukan pengambilan keputusan pada kondisi semi terstruktur dan tidak terstruktur. Pada dasarnya konsep Decision Support Sistem (DSS) hanyalah sebatas pada kegiatan membantu para manajer melakukan penilaian serta menggantikan posisi dan peran manajer. Atau dengan kata lain Sistem Pendukung Keputusan dapat dikatakan sebagai sebuah sistem informasi berbasis komputer yang menggabungkan data dan model guna menyelesaikan masalah semi terstruktur dan tidak terstruktur dengan keterlibatan pengguna secara luas. 
Tujuan utama dari Sistem Pendukung Keputusan ini adalah membantu menyelesaikan masalah semi - terstruktur. Dalam arti keputusan yang akan diambil telah ada syarat dan kriteria yang telah ditetapkan sebelumnya. Sistem Pendukung Keputusan (SPK) dapat membantu mendukung manajer dalam mengambil keputusan. Sistem Pendukung Keputusan (SPK) dapat meningkatkan efektifitas dalam pengambilan keputusan. Dalam pemrosesannya, Sistem Pendukung Keputusan (SPK) dapat menggunakan bantuan dari sistem lain seperti Artificial Intelligence, Expert System, Fuzzy Logic. Pada dasarnya, karakteristik dan kemampuan sebuah Sistem Pendukung Keputusan dapat diuraikan sebagai berikut :

1. Sistem Pendukung Keputusan menyediakan dukungan untuk pengambil keputusan utamanya pada keadaankeadaan semistruktur dan tidak terstruktur dengan menggabungkan penilaian manusia dan informasi komputerisasi.

2. Menyedikan dukungan untuk tingkat manajerial mulai dari eksekutif sampai manajer.

3. Menyedikan dukungan untuk kelompok individu, problem-problem yang kurang terstruktur memerlukan keterlibatan beberapa individu dari departemendepartemen yang lain dalam organisasi.

4. Sistem Pendukung Keputusan menyediakan dukungan kepada independen atau keputusan yang berlanjut.

5. Sistem Pendukung Keputusan memberikan dukungan kepada semua fase dalam proses pembuatan keputusan inteligence, design, choice dan impelementasi.

6. Sistem Pendukung Keputusan mendukung banyak proses dan gaya pengambilan keputusan.

7. Sistem Pendukung Keputusan adaptive terhadap waktu, pembuat keputusan harus reaktif bisa menghadapi perubahan-perubahan kondisi secara cepat dan merubah Sistem Pendukung Keputusan harus fleksibel sehingga pengguna dapat menambah, menghapus, mengkombinasikan, merubah dan mengatur kembali terhadap elemen-elemen dasar.

8. Sistem Pendukung Keputusan mudah digunakan. Pengguna merasa berada dirumah saat bekerja dengan system, seperti user friendly, fleksibilitas, kemampuan penggunaan grafik yang tinggi dan bahasa untuk berinteraksi dengan mesin seperti menggunakan bahasa inggris maka akan menaikan efektifitas dari Sistem Pendukung Keputusan.

9. Sistem Pendukung Keputusan menaikkan efektifitas pembuatan keputusan baik dalam hal ketepatan waktu dan kualitas bukan pada biaya pembuatan keputusan atau biaya pemakaian waktu komputer.

10. Pembuat keputusan dapat mengontrol terhadap tahapan-tahapan pembuatan keputusan seperti pada tahap intelegence, choice dan implementation dan sistem pendukung keputusan diarahkan untuk mendukung pada pembuat keputusan bukan menggantikan posisinya.

11. Memungkinkan pengguna akhir dapat membangun sistem sendiri yang sederhana. Sistem yang besar dapat dibangun dengan bantuan dari spesialis sistem informasi.

12. Sistem Pendukung Keputusan menggunakan modelmodel standar atau buatan pengguna untuk menganalisa keadaankeadaan keputusan. Kemampuan modeling memungkinkan bereksperimen dengan strategi yang berbeda-beda dibawah konfigurasi yang berbeda-beda pula.

13. Sistem Pendukung Keputusan mendukung akses dari bermacam-macam sumber data, format, dan tipe, jangkauan dari sistem informasi geografi pada orientasi obyek

\section{B. Analytic Hierarchy Process (AHP)}

Metode Analytic Hierarchy Process (AHP) dikembangkan oleh Thomas L. Saaty pada tahun 1970 - an ketika di Warston School. Metode Analytic Hierarchy Process (AHP) merupakan salah satu metode yang dapat digunakan dalam sistem pengambilan keputusan dengan memperhatikan faktor - faktor persepsi, preferensi, pengalaman dan intuisi. Analytic Hierarchy Process (AHP) menggabungkan penilaian - penilaian dan nilai - nilai pribadi ke dalam satu cara yang logis.

Metode ini adalah sebuah kerangka untuk mengambil keputusan dengan efektif atas persoalan dengan menyederhanakan dan mempercepat proses pengambilan keputusan dengan memecahkan persoalan tersebut kedalam bagian - bagiannya, menata bagian atau variabel ini dalam suatu susunan hirarki, memberi nilai numerik pada pertimbangan subjektif tentang pentingnya tiap variabel dan mensintesis berbagai pertimbangan ini untuk menetapkan variabel yang mana yang memiliki prioritas paling tinggi dan bertindak untuk mempengaruhi hasil pada situasi tersebut. Metode ini juga menggabungkan kekuatan dari perasaan dan logika yang bersangkutan pada berbagai persoalan, lalu mensintesis berbagai pertimbangan yang beragam menjadi hasil yang cocok dengan perkiraan kita secara intuitif sebagaimana yang dipersentasikan pada pertimbangan yang telah dibuat.

Tahapan - tahapan pengambilan keputusan dalam metode AHP pada dasarnya adalah sebagai berikut :

1. Mendefenisikan masalah dan menentukan solusi yang diinginkan

2. Membuat struktur hirarki yang diawali dengan tujuan umum, dilanjutkan dengan kriteria-kriteria dan alternatif - alternatif pilihan yang ingin di rangking.

3. Membentuk matriks perbandingan berpasangan yang menggambarkan kontribusi relatif atau pengaruh setiap elemen terhadap masing-masing tujuan atau kriteria yang setingkat diatas. Perbandingan dilakukan berdasarkan pilihan atau judgement dari pembuat keputusan dengan menilai tingkat-tingkat kepentingan suatu elemen dibandingkan elemen lainnya. 
4. Menormalkan data yaitu dengan membagi nilai dari setiap elemen di dalam matriks yang berpasangan dengan nilai total dari setiap kolom.

5. Menghitung nilai eigen vector dan menguji konsistensinya, jika tidak konsisten maka pengambilan data (preferensi) perlu diulangi.

6. Nilai eigen vector yang dimaksud adalah nilai eigen vector maksimum yang diperoleh dengan menggunakan matlab maupun dengan manual.

7. Mengulangi langkah, 3, 4, dan 5 untuk seluruh tingkat hirarki.

8. Menghitung eigen vector dari setiap matriks perbandingan berpasangan. Nilai eigen vector merupakan bobot setiap elemen. Langkah ini untuk mensintetis pilihan dalam penentuan prioritas elemen pada tingkat hirarki terendah sampai pencapaian tujuan.

9. Menguji konsistensi hirarki. Jika tidak memenuhi dengan $\mathrm{CR}<0,100$ maka penilaian harus diulangi kembali.

\section{Analisis dan Desain Sistem}

Analisis kebutuhan adalah sebuah proses penemuan, perbaikan, pemodelan,dan spesifikasi. Proses analisis berusaha menjembatani 'gap' antara System Engineering dan software design. System Engineer sendiri mempunyai tugas untuk menspesifikasikan fungsi dan kinerja software, menspesifikasikan interface software dengan elemen lain, menspesifikasikan batasan yang akan dihadapi, dan memperbaiki alokasi software dan membangun model data, fungsi dan domain perilaku yang akan diperlakukan terhadap software. Analisis kebutuhan menyediakan disainer software sebuah model yang dapat ditranslasikan kedalam bentuk data, arsitektur, interface dan disain prosedur. Analisis Kebutuhan membagi area kerjanya kedalam 5 kelompok usaha :

- Pengenalan Masalah

- Pemodelan

- Specification

- Evaluasi dan Sintesa

- Review

\section{HASIL PEMBAHASAN}

Permasalahan yang sering dihadapi adalah panjangnya waktu pencarian perusahaan sebagai subkontraktor, kesulitan untuk menyimpan data, dan perusahaan kadang tidak mendapatkan subkontraktor yang benar-benar pada spesifikasi barang dan harga terbaik.

Dari analisis permasalahan tersebut, dapat dirinci kebutuhan yang dibutuhkan perusahaan. Kebutuhan perusahaan adalah sistem pendukung keputusan yang dapat menyimpan data-data dari subkontraktor dan dapat melakukan scoring dengan cepat, serta memberikan rekomendasi kepada perusahaan. Sistem pendukung keputusan ini mempunyai fasilitas untuk mengelola data master, mengolah hasil penawaran yang masuk, menghasilkan keputusan berupa rekomendasi calon subkontraktor dengan menggunakan metode Analytic Hierarchy Process (AHP), mempunyai fasilitas untuk melihat data customer, lihat profil perusahaan calon subkontraktor, ganti password dan fasilitas untuk membuat kontrak kerjasama, mencetak rekapitulasi semua calon subkontraktor dan laporan mengenai perusahaan yang terpilih sebagai subkontraktor.

\section{A. Fasilitas Sistem}

- Pengelolaan User

Pengelolaan master user meliputi tambah data user ubah data user dan edit data user. Proses tambah user ini hanya bisa dilakukan oleh admin, pada saat admin menambahkan user baru maka program akan melakukan validasi apakah username baru yang diinputkan sudah ada dalam sistem, apabila sudah ada maka proses akan kembali pada input user baru, apabila data user baru belum ada maka proses dilanjutkan dan data akan disimpan dalam database.

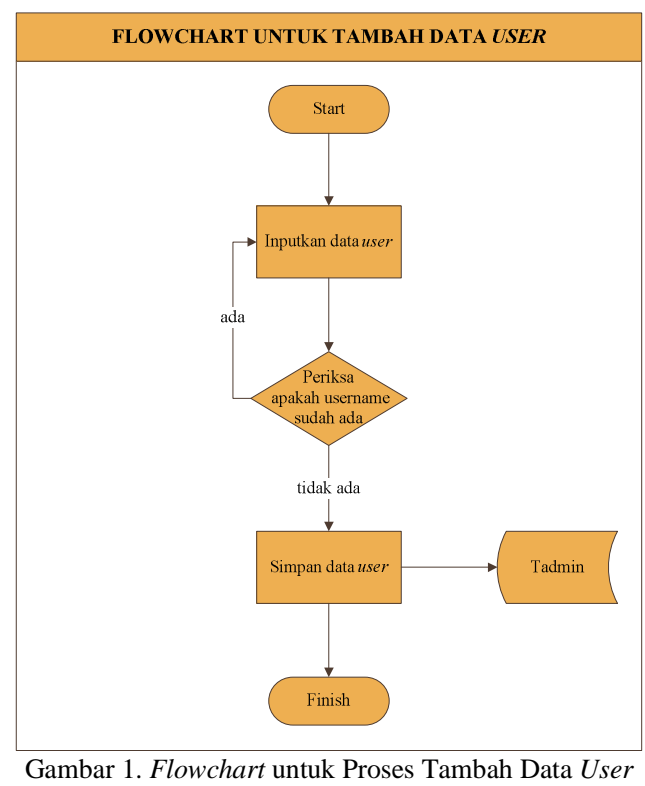

- Pengelolaan Master Customer

Pengelolaan master customer meliputi Proses tambah data master customer ini hanya bisa dilakukan oleh admin, pada saat admin menambahkan customer maka program akan melakukan validasi apakah nama customer baru yang diinputkan sudah ada dalam sistem, apabila sudah ada maka proses akan kembali pada input customer baru, apabila data customer baru belum ada maka proses dilanjutkan dan data akan disimpan dalam database.tambah data customer, ubah data customer dan edit data customer 


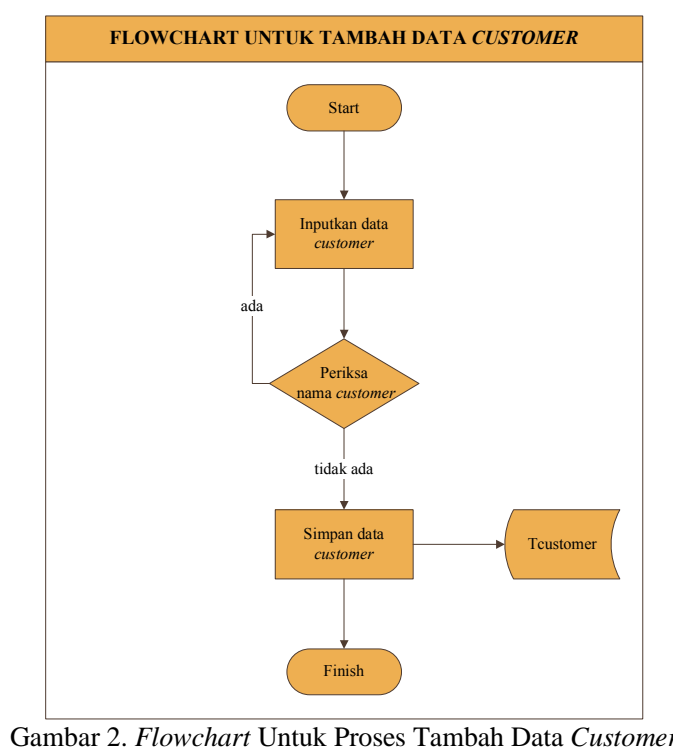

- Pengelolaan Master Subkontraktor: Pengelolaan master subkontraktor meliputitambah data subkontraktor, ubah data subkontraktor dan edit data subkontraktor

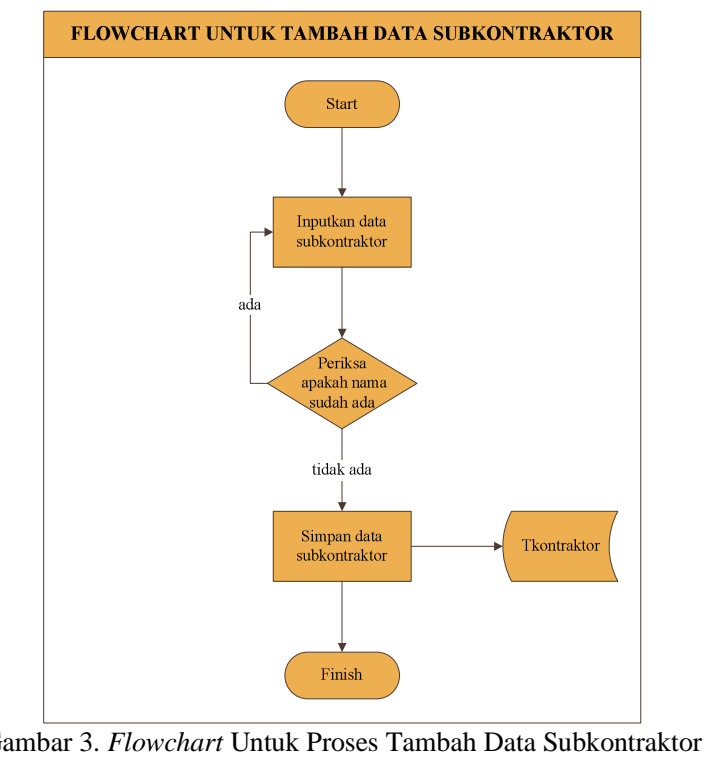

Proses tambah data master subkontraktor ini hanya bisa dilakukan oleh admin, pada saat admin menambahkan subkontraktor maka program akan melakukan validasi apakah nama subkontraktor baru yang diinputkan sudah ada dalam sistem, apabila sudah ada maka proses akan kembali pada input subkontraktor baru, apabila data subkontraktor baru belum ada maka proses dilanjutkan dan data akan disimpan dalam database.

- Pengelolaan Master Proyek: Pengelolaan master proyek meliputi tambah data proyek,ubah data proyek dan edit data proyek

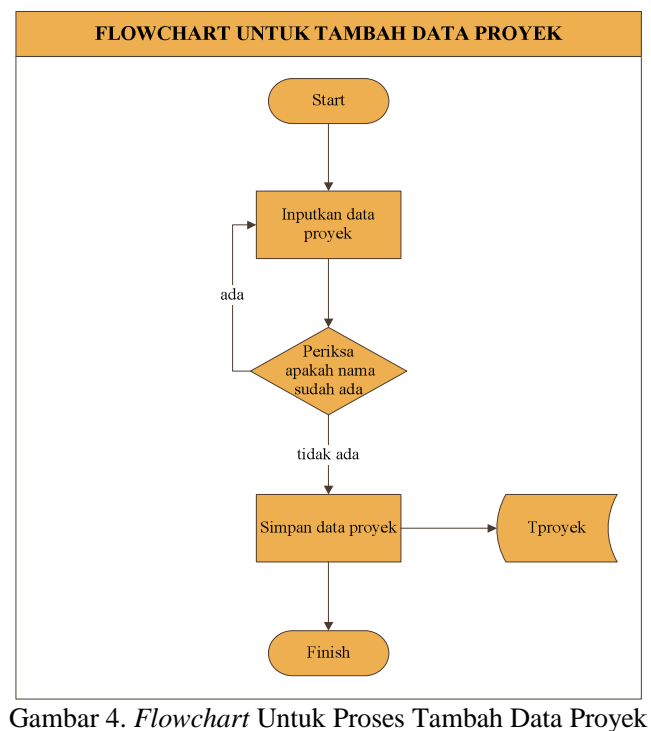

Proses tambah data master proyek ini hanya bisa dilakukan oleh admin, pada saat admin menambahkan proyek maka program akan melakukan validasi apakah nama proyek baru yang diinputkan sudah ada dalam sistem, apabila sudah ada maka proses akan kembali pada input proyek baru, apabila data proyek baru belum ada maka proses dilanjutkan dan data akan disimpan dalam database.

- $\quad$ Proses Kalkulasi Analytic Hierarchy Process (AHP) Pada proses Analytic Hierarchy Process (AHP), yang dilakukan sistem adalah melakukan input kriteria Analytic Hierarchy Process (AHP), setelah itu kriteria yang ada akan dihitung. Setelah itu admin akan melakukan input alternatif. Apabila alternatif sudah benar maka sistem akan melakukan kalkulasi Analytic Hierarchy Process (AHP). Hal ini dilakukan dengan cara mengalikan hasil perhitungan alternatif dengan hasil perhitungan kriteria. Berikut adalah flowchart kalkulasi AHP: 


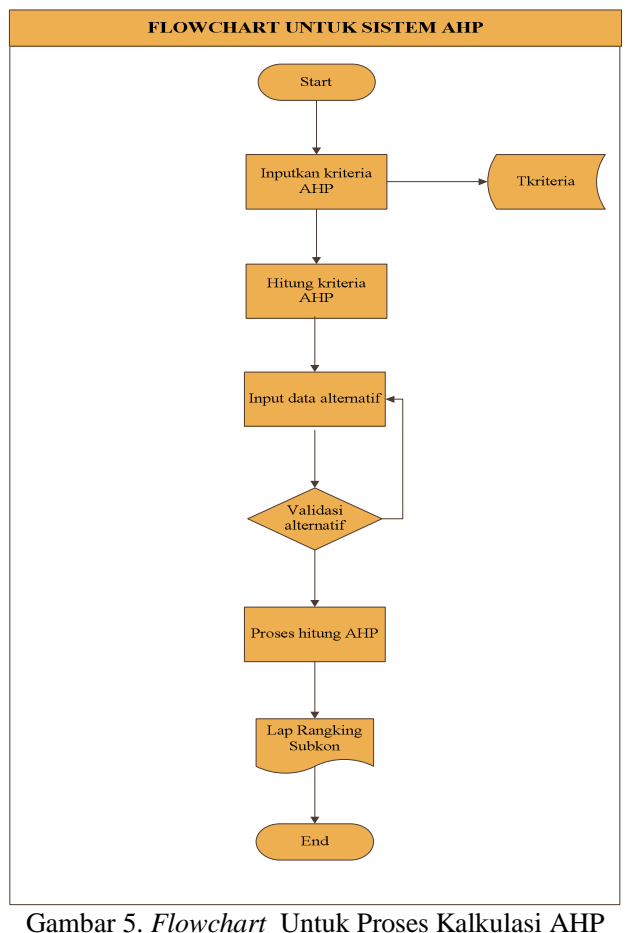

B.Perhitungan dengan metode Analytic Hierarchy Process (AHP)

Berikut adalah contoh atau sampel dari perhitungan Analytic Hierarchy Process (AHP) dari sistem yang dibuat sehingga dapat menghasilkan sebuah urutan (ranking) dari calon-calon subkontraktor yang terdaftar. Dari informasi yang ada, permasalahan bisa di-strukturkan sebagai berikut:

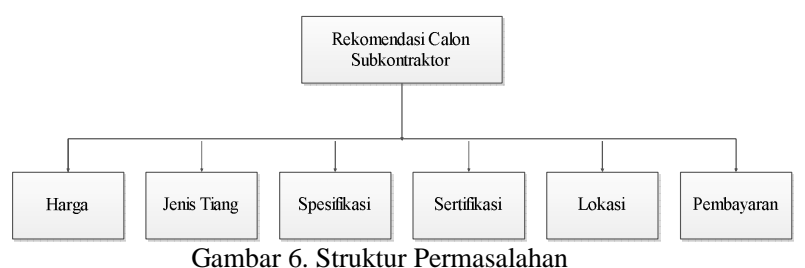

Dari struktur permasalahan diatas, kemudian ditentukan kriteria mana yang penting. Penentuan nilai perbandingan kepentingan antara kriteria yang satu dengan kriteria yang lain dapat ditentukan dengan menggunakan tabel perbandingan berpasangan, dimana nilai perbandingan tersebut menentukan kriteria mana yang lebih penting. Disini penulis mengambil nilai perbandingan sebagai berikut:
Tabel 1. Perbandingan Berpasangan Pertama

\begin{tabular}{|l|c|c|c|c|c|c|}
\hline & Harga & $\begin{array}{c}\text { Jenis } \\
\text { Tiang }\end{array}$ & $\begin{array}{c}\text { Spesifi- } \\
\text { kasi }\end{array}$ & $\begin{array}{c}\text { Sertifi- } \\
\text { kasi }\end{array}$ & Lokasi & $\begin{array}{c}\text { Pemba- } \\
\text { yaran }\end{array}$ \\
\hline Harga & 1 & 1 & 3 & 1 & 3 & 3 \\
\hline $\begin{array}{l}\text { Jenis } \\
\text { Tiang }\end{array}$ & $1 / 3$ & 1 & 1 & 1 & 3 & 3 \\
\hline $\begin{array}{l}\text { Spesifi- } \\
\text { kasi }\end{array}$ & $1 / 3$ & $1 / 3$ & 1 & 1 & 3 & 3 \\
\hline $\begin{array}{l}\text { Sertifi- } \\
\text { kasi }\end{array}$ & $1 / 3$ & $1 / 1$ & $1 / 1$ & 1 & 3 & 3 \\
\hline Lokasi & $1 / 3$ & $1 / 3$ & $1 / 3$ & $1 / 3$ & 1 & 3 \\
\hline $\begin{array}{l}\text { Pemba- } \\
\text { yaran }\end{array}$ & $1 / 3$ & $1 / 3$ & $1 / 3$ & $1 / 3$ & $1 / 3$ & 1 \\
\hline
\end{tabular}

Setelah nilai perbandingan berpasangan telah ditentukan, maka eigen vector dapat dicari dengan cara:

Tabel 2. Perbandingan Berpasangan Kedua

\begin{tabular}{|l|c|c|c|c|c|c|}
\hline & Harga & $\begin{array}{c}\text { Jenis } \\
\text { Tiang }\end{array}$ & $\begin{array}{c}\text { Spesifi- } \\
\text { kasi }\end{array}$ & $\begin{array}{c}\text { Sertifi- } \\
\text { kasi }\end{array}$ & Lokasi & $\begin{array}{c}\text { Pemba- } \\
\text { yaran }\end{array}$ \\
\hline Harga & 1.0000 & 3.0000 & 3.0000 & 3.0000 & 3.0000 & 3.0000 \\
\hline $\begin{array}{l}\text { Jenis } \\
\text { Tiang }\end{array}$ & 0.3333 & 1.0000 & 3.0000 & 1.0000 & 3.0000 & 3.0000 \\
\hline $\begin{array}{l}\text { Spesifi } \\
\text {-kasi }\end{array}$ & 0.3333 & 0.3333 & 1.0000 & 1.0000 & 3.0000 & 3.0000 \\
\hline $\begin{array}{l}\text { Sertifi } \\
\text {-kasi }\end{array}$ & 0.3333 & 1.0000 & 1.0000 & 1.0000 & 3.0000 & 3.0000 \\
\hline Lokasi & 0.3333 & 0.3333 & 0.3333 & 0.3333 & 1.0000 & 3.0000 \\
\hline $\begin{array}{l}\text { Pemba- } \\
\text { yaran }\end{array}$ & 0.3333 & 0.3333 & 0.3333 & 0.3333 & 0.3333 & 1.0000 \\
\hline
\end{tabular}

Setiap nilai perbandingan dijumlah kebawah sehingga hasilnya dapat dilihat pada tabel 2 . Kemudian setiap nilai dinormalisasikan dapat dilihat pada tabel 3 .

\begin{tabular}{|l|c|c|c|c|c|c|}
\hline & Harga & $\begin{array}{c}\text { Jenis } \\
\text { Tiang }\end{array}$ & $\begin{array}{c}\text { Spesifi- } \\
\text { kasi }\end{array}$ & $\begin{array}{c}\text { Sertifi- } \\
\text { kasi }\end{array}$ & Lokasi & $\begin{array}{c}\text { Pemba- } \\
\text { yaran }\end{array}$ \\
\hline Harga & 0.3750 & 0.5000 & 0.3462 & 0.4500 & 0.2250 & 0.1875 \\
\hline $\begin{array}{l}\text { Jenis } \\
\text { Tiang }\end{array}$ & 0.1250 & 0.1667 & 0.3462 & 0.1500 & 0.2250 & 0.1875 \\
\hline $\begin{array}{l}\text { Spesifi } \\
\text {-kasi }\end{array}$ & 0.1250 & 0.0556 & 0.1154 & 0.1500 & 0.2250 & 0.1875 \\
\hline $\begin{array}{l}\text { Sertifi } \\
\text {-kasi }\end{array}$ & 0.1250 & 0.1667 & 0.1154 & 0.1500 & 0.2250 & 0.1875 \\
\hline Lokasi & 0.1250 & 0.0556 & 0.0385 & 0.0500 & 0.0750 & 0.1875 \\
\hline $\begin{array}{l}\text { Pemba- } \\
\text { yaran }\end{array}$ & 0.1250 & 0.0556 & 0.0385 & 0.0500 & 0.0250 & 0.0625 \\
\hline Jum & $\mathbf{1 . 0 0 0 0}$ & $\mathbf{1 . 0 0 0 0}$ & $\mathbf{1 . 0 0 0 0}$ & $\mathbf{1 . 0 0 0 0}$ & $\mathbf{1 . 0 0 0 0}$ & $\mathbf{1 . 0 0 0 0}$ \\
\hline
\end{tabular}

Setelah mendapatkan hasil normalisasi pertama, setiap nilai dijumlahkan kesamping (dapat dilihat pada tabel 3.4.), kemudian dibagi dengan hasil penjumlahan masing-masing baris (dapat dilihat pada tabel 3.4.) yang merupakan eigen vector dari perhitungan kriteria-kriteria ini. 
Tabel 4. Penjumlahan Normalisasi Pertama

\begin{tabular}{|l|c|c|c|c|c|c|c|}
\hline & Harga & $\begin{array}{c}\text { Jenis } \\
\text { Tiang }\end{array}$ & $\begin{array}{l}\text { Spesifi } \\
\text {-kasi }\end{array}$ & $\begin{array}{c}\text { Sertifi } \\
\text {-kasi }\end{array}$ & $\begin{array}{c}\text { Loka } \\
\text { si }\end{array}$ & $\begin{array}{c}\text { Pemba- } \\
\text { yaran }\end{array}$ & Total \\
\hline Harga & 0.3750 & 0.5000 & 0.3462 & 0.4500 & 0.2250 & 0.1875 & $\mathbf{2 . 0 8 3 7}$ \\
\hline $\begin{array}{l}\text { Jenis } \\
\text { Tiang }\end{array}$ & 0.1250 & 0.1667 & 0.3462 & 0.1500 & 0.2250 & 0.1875 & $\mathbf{1 . 2 0 0 3}$ \\
\hline $\begin{array}{l}\text { Spesifi } \\
\text {-kasi }\end{array}$ & 0.1250 & 0.0556 & 0.1154 & 0.1500 & 0.2250 & 0.1875 & $\mathbf{0 . 8 5 8 4}$ \\
\hline $\begin{array}{l}\text { Sertifi } \\
\text {-kasi }\end{array}$ & 0.1250 & 0.1667 & 0.1154 & 0.1500 & 0.2250 & 0.1875 & $\mathbf{0 . 9 6 9 6}$ \\
\hline Lokasi & 0.1250 & 0.0556 & 0.0385 & 0.0500 & 0.0750 & 0.1875 & $\mathbf{0 . 5 3 1 5}$ \\
\hline $\begin{array}{l}\text { Pemba- } \\
\text { yaran }\end{array}$ & 0.1250 & 0.0556 & 0.0385 & 0.0500 & 0.0250 & 0.0625 & $\mathbf{0 . 3 5 6 5}$ \\
\hline Jum & $\mathbf{1 . 0 0 0 0}$ & $\mathbf{1 . 0 0 0 0}$ & $\mathbf{1 . 0 0 0 0}$ & $\mathbf{1 . 0 0 0 0}$ & $\mathbf{1 . 0 0 0 0}$ & $\mathbf{1 . 0 0 0 0}$ & $\mathbf{6 . 0 0 0 0}$ \\
\hline
\end{tabular}

Tabel 5. Normalisasi Kedua

\begin{tabular}{|c|c|}
\hline Normalisasi & Hasil \\
\hline $2,0837 / 6$ & 0.3473 \\
\hline $1,2003 / 6$ & 0.2001 \\
\hline $0.8584 / 6$ & 0.1431 \\
\hline $0.9696 / 6$ & 0.1616 \\
\hline $0.5315 / 6$ & 0.0886 \\
\hline $0,3565 / 6$ & 0.0594 \\
\hline
\end{tabular}

Tabel 5 menunjukkan hasil akhir (eigen vector) dari kriteria yang dibandingkan. Sehingga dapat diambil kesimpulan bahwa:
Harga $\quad=0,3473$ (Paling penting)

Jenis Tiang $=0,2001$

Spesifikasi $=0,1431$

Sertifikasi $=0,1616$

Lokasi $=0,0886$

Pembayaran $=0,0594$

Setelah mendapat eigen vector, nilai consistency ratio yang menentukan konsisten atau tidaknya hasil dari perhitungan ini dapat dihitung, dengan cara :

1. Nilai dari tabel perbandingan berpasangan 2 dikalikan dengan egien vector . (Tabel 6)

Perkalian matrix $=$ baris $\mathrm{x}$ kolom, sehingga hasilnya adalah:

$\begin{array}{cc}\text { Keterangan } & \text { Hasil } \\ \text { Baris 1 } & 2,3054 \\ \text { Baris 2 } & 0,9614 \\ \text { Baris 3 } & 0,2496 \\ \text { Baris 4 } & 0,2019 \\ \text { Baris 5 } & 0,0493 \\ \text { Baris 6 } & 0,0198\end{array}$

2. Mencari $\lambda$ dengan cara hasil perkalian tabel perbandingan berpasangan 2 dengan tabel normalisasi ke-2 dibagi dengan tabel normalisasi ke-2, dapat dilihat pada tabel 7.

Tabel 6. Hasil Perkalian Tabel Perbandingan Berpasangan Kedua Dengan Tabel Normalisasi Kedua

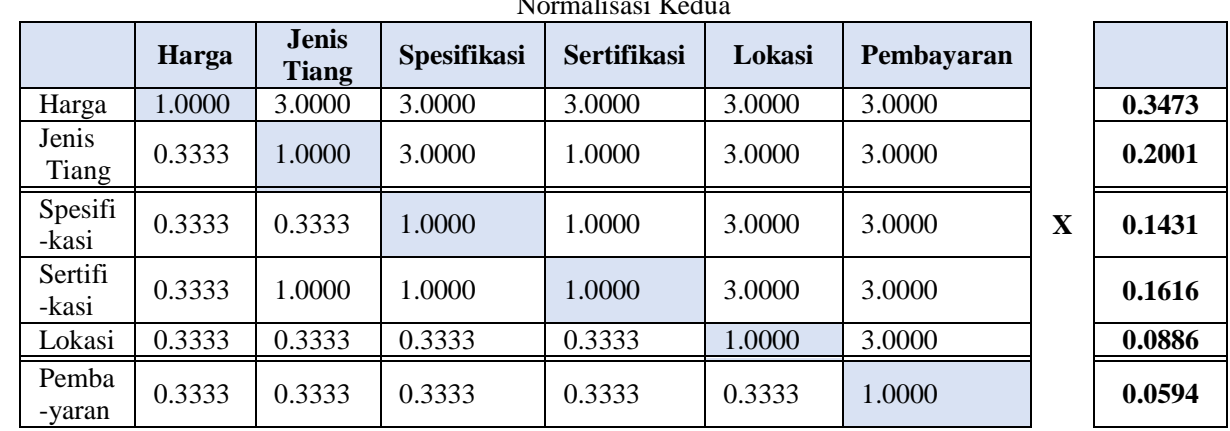

Tabel 7. $\lambda$ (Hasil Bagi Antara Hasil PerbandinganBerpasangan Kedua Dengan Tabel Normalisasi Kedua)

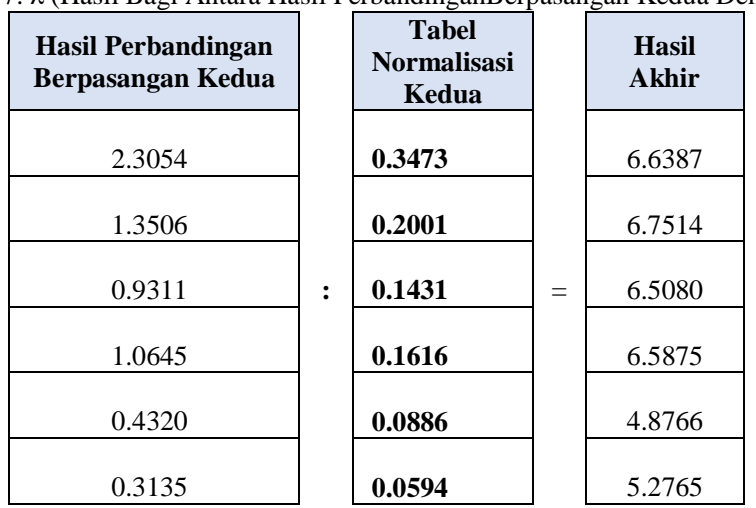


3. Mencari $\lambda_{\text {maks }}$ dengan cara menjumlahkan hasil pada tabel $\lambda$ kemudian dibagi dengan jumlah kriteria yang dibandingkan.

$\lambda_{\text {maks }}=(6,6387+6,7514+6,5080+6,5875+4,8766+5,276$

$$
\text { 5) / } 6=1,0662
$$

4. Mencari Consistency Index (CI) dengan cara $\left(\lambda_{\text {maks }}-\right.$ $\mathrm{n}) /(\mathrm{n}-1)$, dengan $\mathrm{n}$ adalah jumlah kriteria yang dibandingkan.

$$
\mathrm{CI}=(1,0662-6) / 5=-0,9868
$$

5. Menghitung Consistency Ratio dengan cara :

$\mathrm{CR}=\mathrm{CI} /$ Random Consistency Index (RI), dengan RI sebanyak jumlah kriteria yang dibandingkan. $\mathrm{CR}=-0,09868 / \mathrm{RI}_{6}=0,09868 / 1,24=-0,0986$

6. Apabila $\mathrm{CR}<=0,1$ maka perhitungan tersebut dapat dinyatakan konsisten. Jika $\mathrm{CR}>0,1$ maka perhitungan tersebut dapat dinyatakan tidak konsisten. Apabila terdapat dua perhitungan dengan kriteria yang sama memiliki CR yang konsisten, maka perhitungan yang akan dipakai adalah perhitungan yang paling jauh dari 0,1 (yang terkecil)

Sedangkan perhitungan untuk alternatifnya dapat kita contohkan sebagai berikut:

A. Perhitungan untuk HARGA

\begin{tabular}{|l|c|c|c|c|}
\hline & PT GSM & PT BRM & PT BPI & $\begin{array}{c}\text { PT } \\
\text { Rotari }\end{array}$ \\
\hline PT GSM & 1 & $1 / 9$ & 5 & 6 \\
\hline PT BRM & 9 & 1 & 9 & 9 \\
\hline PT BPI & $1 / 5$ & $1 / 9$ & 1 & $1 / 3$ \\
\hline PT Rotari & $1 / 6$ & $1 / 9$ & 3 & 1 \\
\hline
\end{tabular}

Tabel 9. Perbandingan Berpasangan Kedua untuk HARGA

\begin{tabular}{|l|c|c|c|c|}
\hline & PT GSM & PT BRM & PT BPI & PT Rotari \\
\hline PT GSM & 1.0000 & 0.1111 & 5.0000 & 6.0000 \\
\hline PT BRM & 9.0000 & 1.0000 & 9.0000 & 9.0000 \\
\hline PT BPI & 0.2000 & 0.1111 & 1.0000 & 3.0000 \\
\hline PT Rotari & 0.1667 & 0.1111 & 3.0000 & 1.0000 \\
\hline Jumlah & $\mathbf{1 0 . 3 6 6 7}$ & $\mathbf{1 . 3 3 3 3}$ & $\mathbf{1 8 . 0 0 0 0}$ & $\mathbf{1 9 . 0 0 0 0}$ \\
\hline
\end{tabular}

Tabel 10. Penjumlahan Normalisasi Pertama

\begin{tabular}{|l|c|c|c|c|c|}
\hline & $\begin{array}{c}\text { PT } \\
\text { GSM }\end{array}$ & $\begin{array}{c}\text { PT } \\
\text { BRM }\end{array}$ & PT BPI & $\begin{array}{c}\text { PT } \\
\text { Rotari }\end{array}$ & Jumlah \\
\hline $\begin{array}{l}\text { PT } \\
\text { GSM }\end{array}$ & 0.0965 & 0.0833 & 0.2778 & 0.3158 & $\mathbf{0 . 7 7 3 4}$ \\
\hline $\begin{array}{l}\text { PT } \\
\text { BRM }\end{array}$ & 0.8681 & 0.7500 & 0.5000 & 0.4737 & $\mathbf{2 . 5 9 1 8}$ \\
\hline PT BPI & 0.0193 & 0.0833 & 0.0556 & 0.1579 & $\mathbf{0 . 3 1 6 1}$ \\
\hline $\begin{array}{l}\text { PT } \\
\text { Rotari }\end{array}$ & 0.0161 & 0.0833 & 0.1667 & 0.0526 & $\mathbf{0 . 3 3 7 6}$ \\
\hline Jumlah & $\mathbf{1 . 0 0 0 0}$ & $\mathbf{1 . 0 0 0 0}$ & $\mathbf{1 . 0 0 0 0}$ & $\mathbf{1 . 0 0 0 0}$ & $\mathbf{4 . 0 0 0 0}$ \\
\hline
\end{tabular}

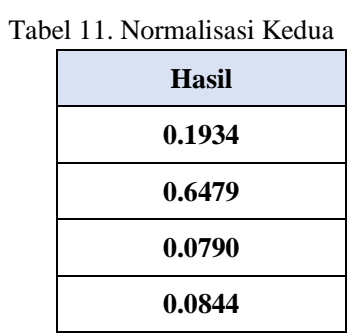

B. Perhitungan untuk JENIS TIANG

Tabel 12. Perbandingan Berpasangan Pertama Untuk JENIS TIANG

\begin{tabular}{|l|c|c|c|c|}
\hline & PT GSM & $\begin{array}{c}\text { PT } \\
\text { BRM }\end{array}$ & $\begin{array}{c}\text { PT } \\
\text { BPI }\end{array}$ & $\begin{array}{c}\text { PT } \\
\text { Rotari }\end{array}$ \\
\hline PT GSM & 1 & 7 & 7 & 1 \\
\hline PT BRM & $1 / 7$ & 1 & 1 & $1 / 7$ \\
\hline PT BPI & $1 / 7$ & 1 & 1 & $1 / 7$ \\
\hline PT Rotari & 1 & 7 & 7 & 1 \\
\hline
\end{tabular}

Tabel 13. Perbandingan Berpasangan Kedua Untuk JENIS TIANG

\begin{tabular}{|l|c|c|c|c|}
\hline & PT GSM & $\begin{array}{c}\text { PT } \\
\text { BRM }\end{array}$ & PT BPI & PT Rotari \\
\hline PT GSM & 1.0000 & 7.0000 & 7.0000 & 1.0000 \\
\hline PT BRM & 0.1429 & 1.0000 & 1.0000 & 0.1429 \\
\hline PT BPI & 0.1429 & 1.0000 & 1.0000 & 0.1429 \\
\hline PT Rotari & 1.0000 & 7.0000 & 7.0000 & 1.0000 \\
\hline Jumlah & $\mathbf{2 . 2 8 5 7}$ & $\mathbf{1 6 . 0 0 0 0}$ & $\mathbf{1 6 . 0 0 0 0}$ & $\mathbf{2 . 2 8 5 7}$ \\
\hline
\end{tabular}

\begin{tabular}{|l|c|c|c|c|c|}
\multicolumn{7}{|c}{ Tabel 14. Penjumlahan Normalisasi Pertama } \\
\hline & $\begin{array}{c}\text { PT } \\
\text { GSM }\end{array}$ & PT BRM & $\begin{array}{c}\text { PT } \\
\text { BPI }\end{array}$ & $\begin{array}{c}\text { PT } \\
\text { Rotari }\end{array}$ & Total \\
\hline $\begin{array}{l}\text { PT } \\
\text { GSM }\end{array}$ & 0.4375 & 0.4375 & 0.4375 & 0.4375 & $\mathbf{1 . 7 5 0 0}$ \\
\hline $\begin{array}{l}\text { PT } \\
\text { BRM }\end{array}$ & 0.0625 & 0.0625 & 0.0625 & 0.0625 & $\mathbf{0 . 2 5 0 0}$ \\
\hline $\begin{array}{l}\text { PT } \\
\text { BPI }\end{array}$ & 0.0625 & 0.0625 & 0.0625 & 0.0625 & $\mathbf{0 . 2 5 0 0}$ \\
\hline $\begin{array}{l}\text { PT } \\
\text { Rotari }\end{array}$ & 0.4375 & 0.4375 & 0.4375 & 0.4375 & $\mathbf{1 . 7 5 0 0}$ \\
\hline $\begin{array}{l}\text { Jumla } \\
\text { h }\end{array}$ & $\mathbf{1 . 0 0 0 0}$ & $\mathbf{1 . 0 0 0 0}$ & $\mathbf{1 . 0 0 0 0}$ & $\mathbf{1 . 0 0 0 0}$ & $\mathbf{4 . 0 0 0 0}$ \\
\hline
\end{tabular}

Tabel 15. Normalisasi Kedua

\begin{tabular}{|c|}
\hline Hasil \\
\hline 0.4375 \\
\hline 0.0625 \\
\hline 0.0625 \\
\hline 0.4375 \\
\hline
\end{tabular}


C. Perhitungan untuk SPESIFIKASI

Tabel 16. Perbandingan Berpasangan Pertama Untuk SPESIFIKASI

\begin{tabular}{|c|c|c|c|c|}
\hline & PT GSM & PT BRM & PT BPI & PT Rotari \\
\hline PT GSM & 1 & 7 & 3 & 2 \\
\hline PT BRM & $1 / 7$ & 1 & 5 & 9 \\
\hline PT BPI & $1 / 3$ & $1 / 5$ & 1 & 2 \\
\hline PT Rotari & $1 / 2$ & $1 / 9$ & $1 / 2$ & 1 \\
\hline
\end{tabular}

Tabel 17. Perbandingan Berpasangan Kedua Untuk SPESIFIKASI

\begin{tabular}{|l|c|c|c|c|}
\hline & PT GSM & PT BRM & PT BPI & PT Rotari \\
\hline PT GSM & 1.0000 & 7.0000 & 3.0000 & 2.0000 \\
\hline PT BRM & 0.1429 & 1.0000 & 5.0000 & 9.0000 \\
\hline PT BPI & 0.3333 & 0.2000 & 1.0000 & 2.0000 \\
\hline PT Rotari & 0.5000 & 0.1111 & 0.5000 & 1.0000 \\
\hline Jumlah & $\mathbf{1 . 9 7 6 2}$ & $\mathbf{8 . 3 1 1 1}$ & $\mathbf{9 . 5 0 0 0}$ & $\mathbf{1 4 . 0 0 0 0}$ \\
\hline
\end{tabular}

Tabel 18. Penjumlahan Normalisasi Pertama

\begin{tabular}{|l|c|c|c|c|c|}
\hline & PT GSM & PT BRM & PT BPI & PT Rotari & Total \\
\hline PT GSM & 0.5060 & 0.8422 & 0.3158 & 0.1429 & $\mathbf{1 . 8 0 6 9}$ \\
\hline PT BRM & 0.0723 & 0.1203 & 0.5263 & 0.6429 & $\mathbf{1 . 3 6 1 8}$ \\
\hline PT BPI & 0.1687 & 0.0241 & 0.1053 & 0.1429 & $\mathbf{0 . 4 4 0 9}$ \\
\hline PT Rotari & 0.2530 & 0.0134 & 0.0526 & 0.0714 & $\mathbf{0 . 3 9 0 4}$ \\
\hline Jumlah & $\mathbf{1 . 0 0 0 0}$ & $\mathbf{1 . 0 0 0 0}$ & $\mathbf{1 . 0 0 0 0}$ & $\mathbf{1 . 0 0 0 0}$ & $\mathbf{4 . 0 0 0 0}$ \\
\hline
\end{tabular}

Tabel 19. Normalisasi Kedua

\begin{tabular}{|c|}
\hline Hasil \\
\hline 0.5081 \\
\hline 0.3432 \\
\hline 0.0937 \\
\hline 0.0550 \\
\hline
\end{tabular}

D. Perhitungan untuk SERTIFIKASI

Tabel 20. Perbandingan Berpasangan Pertama Untuk SERTIFIKASI

\begin{tabular}{|c|c|c|c|c|}
\hline & $\begin{array}{c}\text { PT } \\
\text { GSM }\end{array}$ & PT BRM & PT BPI & PT Rotari \\
\hline PT GSM & $\mathbf{1}$ & $\mathbf{5}$ & $\mathbf{5}$ & $\mathbf{5}$ \\
\hline PT BRM & $\mathbf{1 / 5}$ & $\mathbf{1}$ & $\mathbf{9}$ & $\mathbf{9}$ \\
\hline PT BPI & $\mathbf{1 / 5}$ & $\mathbf{1 / 9}$ & $\mathbf{1}$ & $\mathbf{3}$ \\
\hline PT Rotari & $\mathbf{1 / 5}$ & $\mathbf{1 / 9}$ & $\mathbf{1 / 3}$ & $\mathbf{1}$ \\
\hline
\end{tabular}

Tabel 21. Perbandingan Berpasangan Kedua Untuk SERTIFIKASI

\begin{tabular}{|l|c|c|c|c|}
\hline & PT GSM & PT BRM & PT BPI & PT Rotari \\
\hline PT GSM & 1.0000 & 5.0000 & 5.0000 & 5.0000 \\
\hline PT BRM & 0.2000 & 1.0000 & 9.0000 & 9.0000 \\
\hline PT BPI & 0.2000 & 0.1111 & 1.0000 & 3.0000 \\
\hline PT Rotari & 0.2000 & 0.1111 & 0.3333 & 1.0000 \\
\hline Jumlah & 1.6000 & 6.2222 & 15.3333 & 18.0000 \\
\hline
\end{tabular}

Tabel 22. Penjumlahan Normalisasi Pertama

\begin{tabular}{|l|c|c|c|c|c|}
\hline & PT GSM & PT BRM & PT BPI & PT Rotari & Total \\
\hline PT GSM & 0.6250 & 0.8036 & 0.3261 & 0.2778 & $\mathbf{2 . 0 3 2 4}$ \\
\hline PT BRM & 0.1250 & 0.1607 & 0.5870 & 0.5000 & $\mathbf{1 . 3 7 2 7}$ \\
\hline PT BPI & 0.1250 & 0.0179 & 0.0652 & 0.1667 & $\mathbf{0 . 3 7 4 7}$ \\
\hline PT Rotari & 0.1250 & 0.0179 & 0.0217 & 0.0556 & $\mathbf{0 . 2 2 0 2}$ \\
\hline
\end{tabular}

Tabel 23. Normalisasi Kedua

\begin{tabular}{|c|}
\hline Hasil \\
\hline $\mathbf{0 . 4 5 1 7}$ \\
\hline $\mathbf{0 . 3 4 0 4}$ \\
\hline 0.1102 \\
\hline $\mathbf{0 . 0 9 7 6}$ \\
\hline
\end{tabular}

E. Perhitungan untuk LOKASI

Tabel 24. Perbandingan Berpasangan Pertama Untuk LOKASI

\begin{tabular}{|l|c|c|c|c|} 
& PT GSM & PT BRM & $\begin{array}{c}\text { PT } \\
\text { BPI }\end{array}$ & PT Rotari \\
\hline PT GSM & 1 & 5 & 3 & 2 \\
\hline PT BRM & $1 / 5$ & 1 & 7 & 9 \\
\hline PT BPI & $1 / 3$ & $1 / 7$ & 1 & 2 \\
\hline PT Rotari & $1 / 2$ & $1 / 9$ & $1 / 2$ & 1 \\
\hline
\end{tabular}

Tabel 25. Perbandingan Berpasangan Kedua untuk LOKASI

\begin{tabular}{|l|c|c|c|c|}
\hline & PT GSM & PT BRM & PT BPI & PT Rotari \\
\hline PT GSM & 1.0000 & 5.0000 & 3.0000 & 2.0000 \\
\hline PT BRM & 0.2000 & 1.0000 & 7.0000 & 9.0000 \\
\hline PT BPI & 0.3333 & 0.2000 & 1.0000 & 2.0000 \\
\hline PT Rotari & 0.5000 & 0.1111 & 0.5000 & 1.0000 \\
\hline Jumlah & $\mathbf{2 . 0 3 3 3}$ & $\mathbf{6 . 3 1 1 1}$ & $\mathbf{1 1 . 5 0 0 0}$ & $\mathbf{1 4 . 0 0 0 0}$ \\
\hline
\end{tabular}

Tabel 26. Penjumlahan Normalisasi Pertama

\begin{tabular}{|l|c|c|c|c|c|}
\hline & $\begin{array}{c}\text { PT } \\
\text { GSM }\end{array}$ & $\begin{array}{c}\text { PT } \\
\text { BRM }\end{array}$ & $\begin{array}{c}\text { PT } \\
\text { BPI }\end{array}$ & $\begin{array}{c}\text { PT } \\
\text { Rotari }\end{array}$ & Total \\
\hline PT GSM & 0.4918 & 0.7923 & 0.2609 & 0.1429 & $\mathbf{1 . 6 8 7 8}$ \\
\hline PT BRM & 0.0984 & 0.1585 & 0.6087 & 0.6429 & $\mathbf{1 . 5 0 8 4}$ \\
\hline PT BPI & 0.1639 & 0.0317 & 0.0870 & 0.1429 & $\mathbf{0 . 4 2 5 4}$ \\
\hline PT Rotari & 0.2459 & 0.0176 & 0.0435 & 0.0714 & $\mathbf{0 . 3 7 8 4}$ \\
\hline Jumlah & $\mathbf{1 . 0 0 0 0}$ & $\mathbf{1 . 0 0 0 0}$ & $\mathbf{1 . 0 0 0 0}$ & $\mathbf{1 . 0 0 0 0}$ & $\mathbf{4 . 0 0 0 0}$ \\
\hline
\end{tabular}


Tabel 27. Normalisasi Kedua

\begin{tabular}{|c|}
\hline Hasil \\
\hline 0.4219 \\
\hline 0.3771 \\
\hline 0.1064 \\
\hline 0.0946 \\
\hline
\end{tabular}

\section{F. Perhitungan untuk PEMBAYARAN}

Tabel 28. Perbandingan Berpasangan Pertama Untuk PEMBAYARAN

\begin{tabular}{|l|c|c|c|c|}
\hline & PT GSM & PT BRM & PT BPI & PT Rotari \\
\hline PT GSM & 1 & 5 & 3 & 2 \\
\hline PT BRM & $1 / 5$ & 1 & 2 & 2 \\
\hline PT BPI & $1 / 3$ & $1 / 2$ & 1 & 9 \\
\hline PT Rotari & $1 / 2$ & $1 / 2$ & $1 / 9$ & 1 \\
\hline
\end{tabular}

Tabel 29. Perbandingan Berpasangan Kedua Untuk PEMBAYARAN

\begin{tabular}{|l|c|c|c|c|}
\hline & PT GSM & PT BRM & PT BPI & PT Rotari \\
\hline PT GSM & 1.0000 & 5.0000 & 3.0000 & 2.0000 \\
\hline PT BRM & 0.2000 & 1.0000 & 2.0000 & 2.0000 \\
\hline PT BPI & 0.3333 & 0.5000 & 1.0000 & 9.0000 \\
\hline PT Rotari & 0.5000 & 0.5000 & 0.1111 & 1.0000 \\
\hline Jumlah & $\mathbf{2 . 0 3 3 3}$ & $\mathbf{7 . 0 0 0 0}$ & $\mathbf{6 . 1 1 1 1}$ & $\mathbf{1 4 . 0 0 0 0}$ \\
\hline
\end{tabular}

\begin{tabular}{|l|c|c|c|c|c|}
\multicolumn{1}{c|}{ Tabel 30. Penjumlahan Normalisasi Pertama } \\
\hline & $\begin{array}{c}\text { PT } \\
\text { GSM }\end{array}$ & $\begin{array}{c}\text { PT } \\
\text { BRM }\end{array}$ & $\begin{array}{c}\text { PT } \\
\text { BPI }\end{array}$ & $\begin{array}{c}\text { PT } \\
\text { Rotari }\end{array}$ & Total \\
\hline PT GSM & 0.4918 & 0.7143 & 0.4909 & 0.1429 & $\mathbf{1 . 8 3 9 9}$ \\
\hline PT BRM & 0.0984 & 0.1429 & 0.3273 & 0.1429 & $\mathbf{0 . 7 1 1 3}$ \\
\hline PT BPI & 0.1639 & 0.0714 & 0.1636 & 0.6429 & $\mathbf{1 . 0 4 1 9}$ \\
\hline $\begin{array}{l}\text { PT } \\
\text { Rotari }\end{array}$ & 0.2459 & 0.0714 & 0.0182 & 0.0714 & $\mathbf{0 . 4 0 6 9}$ \\
\hline Jumlah & $\mathbf{1 . 0 0 0 0}$ & $\mathbf{1 . 0 0 0 0}$ & $\mathbf{1 . 0 0 0 0}$ & $\mathbf{1 . 0 0 0 0}$ & $\mathbf{4 . 0 0 0 0}$ \\
\hline
\end{tabular}

Hasil akhirnya dapat kita lihat pada perhoitungan tabel 32:

Tabel 31. Normalisasi Kedua
\begin{tabular}{|c|}
\hline Hasil \\
\hline $\mathbf{0 . 4 6 0 0}$ \\
\hline $\mathbf{0 . 1 7 7 8}$ \\
\hline $\mathbf{0 . 2 6 0 5}$ \\
\hline $\mathbf{0 . 1 0 1 7}$ \\
\hline
\end{tabular}

Tabel 32. Perkalian Dari Tabel Normalisasi Kedua Alternatif Dan Kriteria

\begin{tabular}{|l|c|c|c|c|c|c|}
\hline Nama & Harga & $\begin{array}{c}\text { Jenis } \\
\text { Tiang }\end{array}$ & Spesifikasi & Sertifkasi & Lokasi & Pembayaran \\
\hline PT GSM & 0.1934 & 0.4375 & 0.4517 & 0.5081 & 0.4219 & 0.4600 \\
\hline PT BRM & 0.6479 & 0.0625 & 0.3404 & 0.3432 & 0.3771 & 0.1778 \\
\hline PT BPI & 0.0790 & 0.0625 & 0.1102 & 0.0937 & 0.1064 & 0.2605 \\
\hline PT Rotari & 0.0844 & 0.4375 & 0.0976 & 0.0550 & 0.0946 & 0.1017 \\
\hline
\end{tabular}

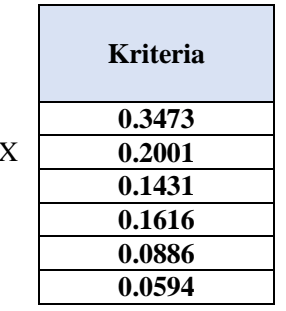

Tabel 33. Hasil Akhir AHP

\begin{tabular}{|l|c|}
\hline \multicolumn{1}{|c|}{ Nama } & Hasil \\
\hline PT GSM & 0.3661 \\
\hline PT BRM & 0.3857 \\
\hline PT BPI & 0.0958 \\
\hline PT Rotari & 0.0594 \\
\hline
\end{tabular}

Dari tabel hasil normalisasi kedua dari masing-masing alternatif kita kalikan dengan tabel hasil normalisasi kedua dari kriteria yang kita pakai yaitu 6 kriteria. Maka dari hasil diatas dapat kita lihat subkontraktor terpilih adalah PT GSM. 
Adapun desain dari aplikasi Sistem Pendukung Keputusan untuk penentuan Sub Kontraktor dengan Metode AHP dapat dilihat pada beberapa gambar berikut:

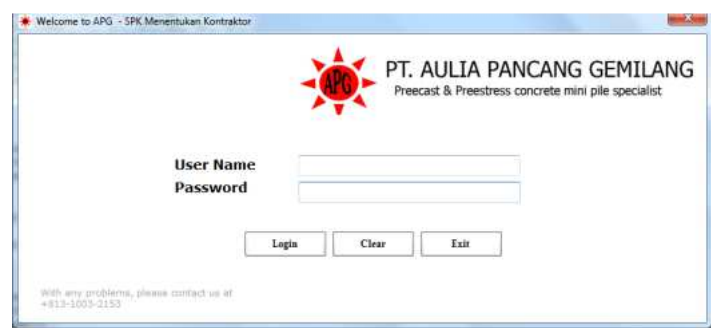

Gambar 7. Form Login Aplikasi SPK PT. AULIA PANCA GEMILANG

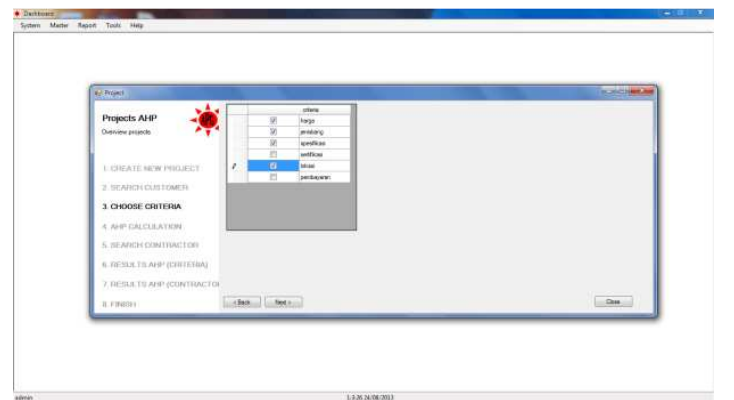

Gambar 8. Form Pemilihan Kriteria

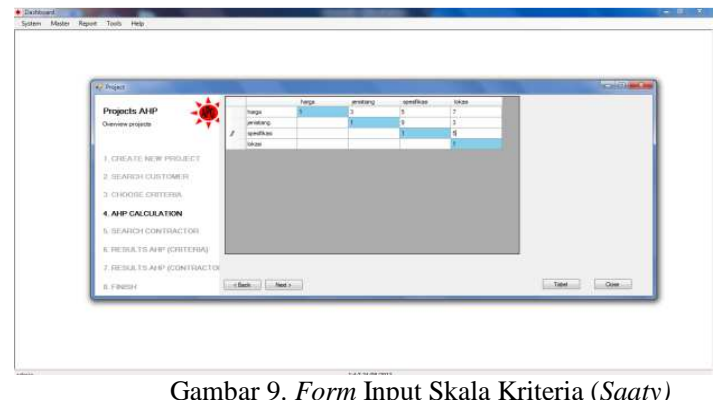

Gambar 9. Form Input Skala Kriteria (Saaty)

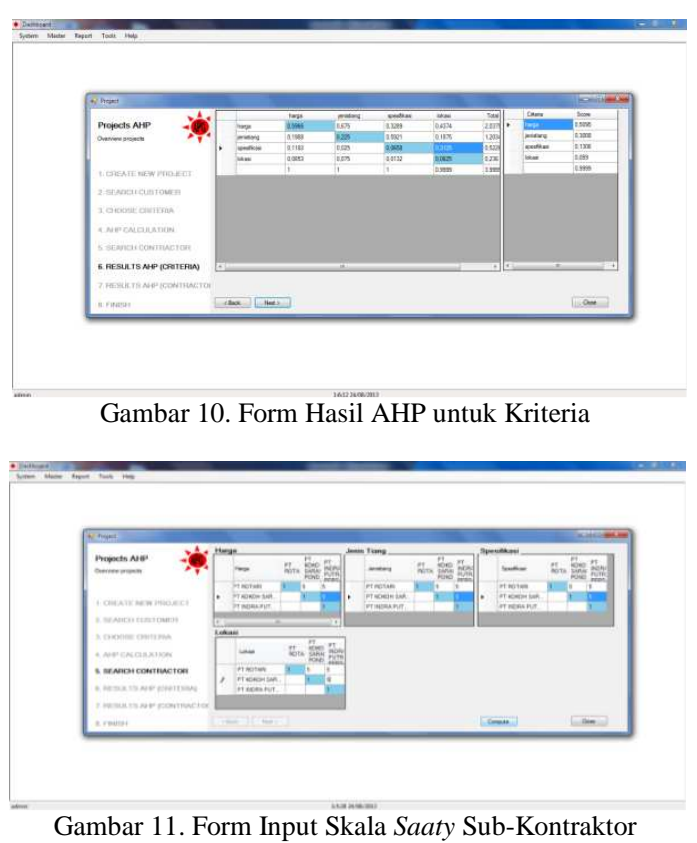

Gambar 11. Form Input Skala Saaty Sub-Kontraktor
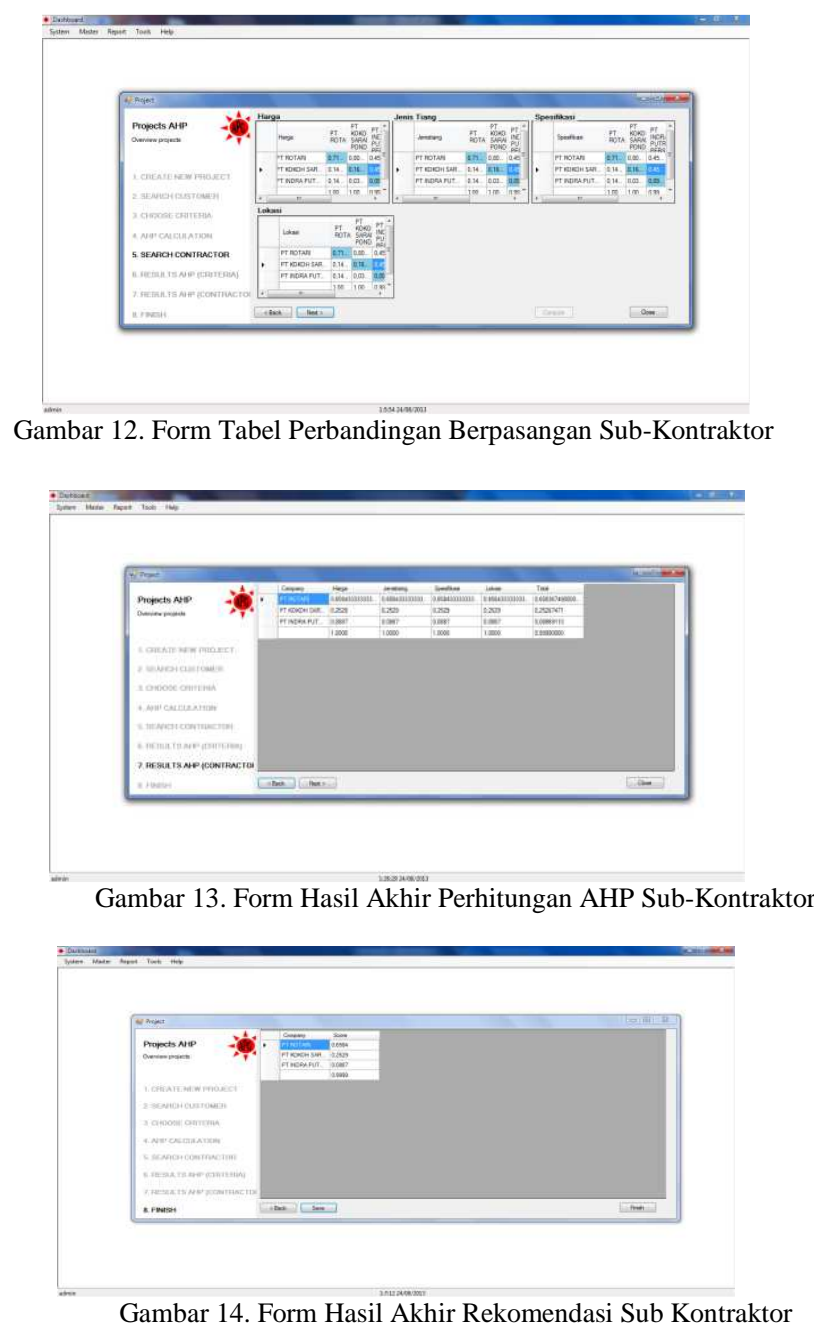

IV. KESIMPULAN DAN SARAN

A. Kesimpulan

Dari hasil perumusan masalah hingga penyelesaian program ini, dapat ditarik beberapa kesimpulan, antara lain:

- Keenam kriteria yang digunakan dalam Sistem Pendukung Keputusan untuk Penentuan Calon Subkontraktor ini didapatkan dari hasil penelitian terhadap history dan pengalaman proyek yang selama ini telah dikerjakan, selanjutnya pemilihan kriteria yang digunakan dalam setiap proyek berdasarkan keputusan direksi, dimana kriteria yang dipakai berbeda-beda tergantung kondisi proyek yang akan dikerjakan.

- Dengan adanya Sistem Pendukung Keputusan Untuk Penentuan Calon Subkontraktor ini maka redudansi pada perusahaan dapat teratasi, dan perusahaan memiliki sistem pendukung keputusan untuk membantu perusahaan dalam menentukan calon subkontraktor yang tepat 
B. Saran

Pembuatan program aplikasi Sistem Pendukung Keputusan ini masih jauh dari sempurna. Untuk itu, saran-saran yang dapat diberikan antara lain:

- Sistem ini masih berbasis desktop sehingga proses penawaran masih sedikit lambat. Pada pengembangannya proses ini bisa dilakukan secara online, dimana akan memudahkan perusahaan calon subkontraktor untuka mendaftar dengan cepat.

- Sistem ini dapat dikembangkan lebih lanjut dengan menambahkan beberapa proses yang belum tersedia, yang dapat mendukung sistem tersebut, seperti proses penambahan kriteria baru.

\section{REFERENSI}

[1] Haas Raines, Dr. \& Meixner Oliver, Dr. (2012) An illustrated guide to the Analytic Hierarchy Process. Vienna.

[2] Nurdin Bahtiar,MT, Helmie Arif Wibawa,M.Cs, Sukmawati Nur Endah,M.Kom, Sutikno,M.Cs, (2012) Sistem Pendukung Keputusan, Komputasi dan Simulasi. Graha Ilmu.

[3] Saaty, T.L. (2004) Fundamental of the analytic hierarchy process dependence and feedback in decision-making with a single network. Pittsburgh.

[4] Sebnemburnaz* \& Topcu llker. (2006) A multiple-criteria decision-making approach for the evaluation of retail location. Wiley InterScience 